\title{
firISGUC.ORG
}

"İȘ, GÜC̣" ENDÜSTRi iLIȘKiLERi VE INSAN KAYNAKLARI DERGisi

"IS, GUC" INDUSTRIAL RELATIONS AND HUMAN RESOURCES JOURNAL

\section{Kamu Örgütlerinde Girişimcilik}

Entrepreneurship in the Public Organizations

\section{Yrd.Doç.Dr.Ali Osman ÖZTÜRK}

İstanbul Ticaret Üniversitesi

Ekim/October 2012, Cilt/Vol: 14, Sayı/Num: 4, Page: 151-169 ISSN: 1303-2860, DOI: 10.4026/1303-2860.2012.0215.x

Makalenin on-line kopyasına erişmek için:

http://www.isguc.org/? $\mathrm{p}=$ article\&id $=500 \&$ vol $=14 \&$ num $=4 \& y e a r=2012$

To reach the on-line copy of article:

http://www.isguc.org/? $\mathrm{p}=$ article\&id $=500 \&$ vol=14\&num $=4 \& y e a r=2012$

Makale İçin İletişim/Correspondence to: 
(c) 2000- 2012

"İ̧̧üç̧" Endüstri İlişkileri ve İnsan Kaynakları Dergisi

"İşǚç" Industrial Relations and Human Resources Journal

Ekim/October 2012, Cilt/Vol: 14, Say1/Num: 4
ISSN: 1303-2860, Journal DOI: 10.4026/1303-2860

İş,Güç, Endüstri İlişkileri ve İnsan Kaynakları Dergisi, yılda dört kez yayınlanan hakemli, bilimsel elektronik dergidir. Çalışma hayatına ilişkin makalelere yer verilen derginin temel amacı, belirlenen alanda akademik gelişime ve paylaşıma katkıda bulunmaktadır.

İş, Güç, Endüstri İlişkileri ve İnsan Kaynakları Dergisi, 'Türkçe’ ve ‘İngilizce' olarak iki dilde makale yayınlanmaktadır.

Dergimiz İş,Güç ulusal ve uluslararası birçok indekste taranmaktadır. (Cabells Directory, Ebsco Socindex, Index Islamicus, Index Copernicus, Worldwide Political Science Abstracts, Sociological Abstract, Ulakbim Sosyal Bilimler Veritanı, Asos Index)

Editör/Editor-in-Chief

Aşkın Keser (Uludağ University)

Editör Yardımcılarn/Co-Editors

K.Ahmet Sevimli (Uludağ University)

Gözde Yilmaz (Marmara University)

Uygulama/Design

Yusuf Budak (Kocaeli Universtiy)

Tarandiğı Indeksler

ASOS INDEX

CABELLS DIRECTORY

EBSCO SOCINDEX

Index ISLAMICUS

Index COPERNICUS

Sociological Abstract

ULAKBIM Sosyal Bilimler

Veritanı

Worldwide Political Science

Abstracts

\author{
Yayın Kurulu / Editorial Board \\ Yrd.Doç.Dr.Zerrin Furat (Uludă̆ University) \\ Doç.Dr.Aşkın Keser (Uludağ University) \\ Prof.Dr.Ahmet Selamoğlu (Kocaeli University) \\ Yrd.Doç.Dr.Ahmet Sevimli (Uludağ University) \\ Doç.Dr.Abdulkadir Şenkal (Kocaeli University) \\ Doç.Dr.Gözde Yılmaz (Marmara University) \\ Dr.Memet Zencirkıran (Uludağ University)
}

Uluslararası Danışma Kurulu / International Advisory Board Prof.Dr.Ronald Burke (York University-Kanada)

Assoc.Prof.Dr.Glenn Dawes (James Cook University-Avustralya)

Prof.Dr.Jan Dul (Erasmus University-Hollanda)

Prof.Dr.Alev Efendioğlu (University of San Francisco-ABD)

Prof.Dr.Adrian Furnham (University College London-İngiltere)

Prof.Dr.Alan Geare (University of Otago- Yeni Zellanda)

Prof.Dr. Ricky Griffin (TAMU-Texas AEM University-ABD)

Assoc. Prof. Dr. Diana Lipinskiene (Kaunos University-Litvanya)

Prof.Dr.George Manning (Northern Kentucky University-ABD)

Prof. Dr. William (L.) Murray (University of San Francisco-ABD)

Prof.Dr.Mustafa Özbilgin (Bruner University-UK)

Assoc. Prof. Owen Stanley (James Cook University-Avustralya)

Prof.Dr.Işık Urla Zeytinoğlu (McMaster University-Kanada)

Ulusal Danışma Kurulu I National Advisory Board
Prof.Dr.Yusuf Alper (Uludă̆ University)
Prof.Dr.Veysel Bozkurt (İstanbul University)
Prof.Dr.Toker Dereli (Işık University)
Prof.Dr.Nihat Erdoğmuş (İstanbul Şehir University)
Prof.Dr.Ahmet Makal (Ankara University)
Prof.Dr.Ahmet Selamoğlu (Kocaeli University)
Prof.Dr.Nadir Suğur (Anadolu University)
Prof.Dr.Nursel Telman (Maltepe University)
Prof.Dr.Cavide Uyargil (İstanbul University)
Prof.Dr.Engin Yildırım (Anayasa Mahkemesi)
Doç.Dr.Arzu Wasti (Sabancı University)

Dergide yayınlanan yazılardaki görüşler ve bu konudaki sorumluluk yazarlarına aittir.

Yayınlanan eserlerde yer alan tüm içerik kaynak gösterilmeden kullanılamaz.

All the opinions written in articles are under responsibilities of the outhors.

The published contents in the articles cannot be used without being cited. 


\title{
Kamu Örgütlerinde Girişimcilik
}

\author{
Entrepreneurship in the Public Organizations
}

\author{
Yrd.Doç.Dr.Ali Osman ÖZTÜRK \\ İstanbul Ticaret Üniversitesi
}

\begin{abstract}
Özet
Girişimciliği özel sektör uygulamaları bağlamında inceleyen çalışmalarda girişimcilik sürecini risk alma, yenilikçilik ve proaktivite boyutlarıyla ele alan bir yaklaşım hakimdir. Halbuki, son otuz yıldır kamu yönetimi literatüründe de yer bulmaya başlamış olan girişimcilik kavramının özel sektörde gözlenen süreçlerden farklı olması gereği yoğun olarak tartışılmaktadır. Bu anlamda kamu örgütlerini özel sektördekilerden ayıran yapısal, yönetsel ve kültürel niteliklerine uygun olarak gelişen girişimcilik yaklaşımlarına ihtiyaç duyulmakla birlikte, kamu yönetimi literatüründe bu konuda ortak bir perspektife ulaşılmadığı gözlenmektedir. Bu çalışmada kamu hizmeti sunan geleneksel kamu örgütlerinin yapısal, yönetsel ve kültürel karakteristikleri çerçevesinde girişimci aktivitelere ne denli elverişli oldukları risk alma, yenilikçilik ve proaktivite boyutlarıla detaylı bir şekilde incelenerek, kamu yönetimi akademisyen ve uygulayıcılarına katkı sağlayacağı düşünülen değerlendirmeler yapılmıştır.
\end{abstract}

Anahtar Kelimeler: Kamu örgütleri, girişimcilik, risk alma, yenilikçilik, proaktivite.

\begin{abstract}
The studies focused on entrepreneurship process at private sector organizations often make use of an approach including risk taking, innovation, and proactiveness dimensions of entrepreneurship. During last three decades, entrepreneurship has been the subject of in-depth studies of public administration literature while emphasizing its different aspects from the private sector practices. Although there is a need for a unique entrepreneurship approach for public sector organizations based on their structural, managerial, and cultural aspects, it seems that there is no common entrepreneurship perspective developed by public administration scholars. In the light of pertaining literature, this study explores applicability of risk taking, innovation, and proactiveness dimensions of entrepreneurship to the public organizations with their structural, managerial, and cultural characteristics while providing useful assessments to Turkish public management scholars and practitioners.
\end{abstract}

Keywords: Public organizations, entrepreneurship, risk taking, innovativeness, proactiveness. 


\section{Giriş}

En genel tanımı ile girişimcilik, ticari bir öngörüyü başarılı bir teşebbüse dönüştürmeye yönelik bireysel çabalar bütünüdür (Kearney, Hisrich ve Roche, 2009:27). Bireysel ölçekte girişimcilik risk alma, yenilikçilik ve proaktivite eğilimi yönleriyle ele alınırken; örgütsel ölçekte girişimcilik bir süreç olarak incelenmektedir. Özel sektör kuruluşlarının kar makzimizasyonu ve rekabet edebilirlik amaçları yönünden konuyu ele alan bu yaklaşıma göre kurumsal girişimcilik, bir işletmenin sahip olduğu karar alma biçimleri ve yöntemleri ile üretim faaliyetlerinde yenilikçilik, risk alma ve proaktivite boyutlarını içeren stratejik bir eğilimdir (Rutherford ve Holt, 2007: 430; Espinosa ve Saunes, 2011:414).

Özel sektör yöntem ve araçlarının kamu sektöründe verimliliği ve etkinliği arttırmak için uygulanabileceğini savunan "yeni kamu yönetimi' (New Public Management) akımı ile birlikte, kamu örgütlerinin hantallaşan ve verimsizleșen alanlarının, özel sektörde rüştü ispatlanmış yönetim teknik ve yaklaşımlariyla daha verimli bir hale getirilebileceği yönünde 1990'lardan bu yana yoğun tartışmalar yapılmaktadır (Borins, 1998:42; Boyett, 1997:82; Drucker, 1985:2-7; Osborne ve Gaebler, 1992:325-328). Girişimci yaklaşımların kamu sektörüne getireceği potansiyel yarar ve zararları ele alınırken, girişimciliğin özünü oluşturan risk alma, yenilikçilik ve proaktif eğilimlerin özel sektörde uygulandığı gibi kamu örgütlerine aktarılamayacağı gerçeğinden hareketle; kamu örgütlerinin yapısal, yönetsel ve kültürel karakteristikleri çerçevesinde girişimciliğin kapsam ve pratiğinin dikkatle incelenmesi gerekmektedir (Boyett, 1997 :8899; Sadler, 2000:39; Bernier ve Hafsi, 2007: 498-499; Currie vd., 2008: 1003-1006; Kim, 2010:25).

$\mathrm{Bu}$ çalışmanın temel amacı, girişimcilik sürecini kamu kurum ve kuruluşlarının yapisal, yönetsel ve kültürel karakteristikleri çerçevesinde detaylı bir şekilde değerlendirmek ve daha verimli kamu hizmeti sunmayı amaçlayan kamu örgütlerinde girişimci faaliyetlerin kapsam ve sinırlarını analiz etmektir.

\section{Kavramsal Çerçeve}

Kamu sektöründe girişimcilik nosyonuna yer veren ilk çalışmalara, kamu kurumlarının etkinliğini artırması ve küresel düzeydeki değişimlerin oluşturduğu çevre şartlarına ayak uydurabilmesi için, yeni "kamu yöneticiliği" (public managerialism), yenilikçilik ve girişimciliği önceleyen periyodik reform ihtiyaçlarının dile getirilmeye başlandığ 1980 'li yıllarda rastlanmaktadır (Forster vd., 1996:3). Bu dönemde yayginlaşan, sosyal anlamda muhafazakar ama ekonomik anlamda neo-liberal bir açılım, girişimci idare kavramını ve giderek hantallaşan bürokratik yapılara alternatif modellerin geliştirilmesi fikrini tartışmaya açmıştır (Eryılmaz, 2010:17-22). Bu dönemde özel sektör kurumlarında başarılı olduğu gözlenen toplam kalite yönetimi, stratejik planlama, performans temelli yönetim vs. gibi yeni yönetim sistem ve süreçlerinin kamu sektörüne aktarılmasının yerinde olacağ 1 fikri yaygınlaşmaya başlamıştır. Bütün bu gelişmelerin temelinde, vatandaşlara daha iyi hizmet sunmayı hedefleyen kamu kurumlarının, kamu kaynaklarının etkin kullanımı ile hizmet kalitelerini nasil yükseltebilecekleri sorusuna cevap bulma çabası yatmaktadır (Borins, 1998: 34-40; Boyett, 1996: 79; Drucker, 1985: 12-36; Osborne ve Gaebler, 1992: 311-330).

Kanımızca, girişimcilik kavramı çok disiplinli ve çok boyutlu yönü ile ele alınması gereken bir kavramdır. Son yıllarda kamu yönetimi alanında yapılan araştırma ve yayınlar incelendiğinde, aşağıdaki kamu girişimciliği tanımlarının genel kabul gördüğü ortaya çıkar:

- Yeni işlem ve yöntemleri ortaya atarak kamu organizasyonlarında başarıyla uygulanabilir hale dönüştüren yenilikçi süreçtir (Roberts ve King, 1991: 147).

- Kamusal amaçlar doğrultusunda mev- 
cut sistemin üzerine kurulduğu standart yönetim süreçlerinin ve müdehalelerinin dışına çıkarak yenilikçiliğin, risk almanın ve proaktifliğin söz konusu olduğu örgütsel bir süreçtir (Stone, 1992:31-32).

- Toplumsal düzeyde oluşan firsat ve imkanları en iyi şekilde değerlendirmek üzere kamu ve özel sektör kaynaklarını daha önce bir örneğine rastlanmayan bir biçimde biraraya getirmek suretiyle vatandaşlar için değer yaratan bir süreçtir (Morris ve Jones, 1999: 74).

- Yöneticilerin toplumun ihtiyaçlarını belirleme ve uygun çözüm önerileri üretmelerine destek olmak amaciyla toplumsal düzeyde enerji ve yaratıcıl1ğın ön plana çıkarıldığı sürecin kullanilmasidir (Edwards, Jones, Lawton ve Llewellyn, 2002: 1548).

- Kamu kaynaklarını belli oranda risk içeren karar ve politikalar doğrultusunda kullanmak suretiyle halk için değer yaratma çabasıdır (Gansler, 2003: 37).

Bu tanimlarda bireysel anlamda kamu girişimcisi profilinin çizilmesinden ziyade "girişimci eğilim" ve "girişimci yönetim" anlayışının hakim olduğu kurumsal girişimcilik bakış açısının mevcut olduğu söylenebilir. Kamu yönetimi literatüründe genel kabul gören girişimlik tanımlarının, girişimciliği genellikle örgütsel düzeyde bir "süreç" olarak kabul ettiği ve girişimci bireylerden daha çok örgüt-içi aktiviteleri esas aldığı görülmektedir. Kamu sektöründeki girişimcilik süreçlerinin, bir kamu görevlisinin yenilikçi bir fikri, bir kavramı veya bir yöntemi ortaya atmasıyla başlayan; bunun, kamu yararına dönüşen bir çıktı haline gelinceye kadar geçirdiği tüm evreleri kapsayan bir yönü mevcuttur (Zampetakis ve Moustakis, 2010:873). Örgütsel düzeyde ekonomik belirsizliklerle başetme, planlama, koordinasyon ve idare gibi fonksiyonel girişimcilik öğelerinden bahsedilebileceği gibi, kar amacı gütmeksizin yanlızca idari perfor- mansı arttırmayı hedefleyen kamu kurumlarında girişimci süreç risk alma, yenilikçilik ve proaktivite gibi üç temel boyutta irdelenebilecektir (Kim, 2010: s. 6).

\section{Kamu Örgütlerinde Risk Alma}

Risk almak, belirlsizlik ya da karmaşanın hakim olduğu bir süreç sonucunda elde edilecek üstünlük için önceden belirlenmiş kayıplara tahammül ederek söz konusu girişimden geri durmamaktır (Bulut vd., 2008: 1403; Hean vd., 126). Literatürde girişimcilik faaliyetinin temel nüvesinin risk almak olduğu tüm çalışmaların hem fikir olduğu bir noktadır. Tarihsel açıdan ilk dönem girişimcilik tanımı yapan ekonomistlerin firma sahibinin karlılığ 1 artırma amacıyla fırsatları en iyi şekilde değerlendirmek üzere gerekli yenilikleri gerçekleştirmekten ve risk almaktan çekinmedikleri vurgusu göze çarpar (Peneder, 2009 :80). Risk alan bir girişimci, geliştirdiği yeni ürün, hizmet ya da üretim yöntemlerinin muhtemel sonuçlarını hesap ederek bilinçli kararlar alan kişidir. Dolayısıyla girişimci için risk alma, elde edilecek yüksek karlılık adına, muhtemel maddi kayıplara neden olabilecek, zor ve belirsiz kararların sorumluluğunu ve sonuçlarını göze alabilmektir.

Risk almayı kamu örgütleri açısından ele aldığımızda bir takım sinırlılıklardan bahsetmemiz gerekmektedir. Kamu fonlarınin yerinde kullanılması, kamu hizmetlerinin kesintisiz olarak sürdürülmesi ve siyasi kontrol sistemi gibi sebeplerden dolayı, kamu örgütlerinin risk taşıyan karar alma, yenilikçi ve proaktif faaliyetlerde bulunma inisiyatifleri özel sektör örgütlerine göre daha kısıtlıdır. Diğger bir ifadeyle, özel sektör organizasyonları için kabul edilen "yüksek risk, yüksek kâr" mantığının kamu hizmeti sunan kurumlar için de geçerli olduğu düşünülmemelidir (Eggers ve O'Leary :1995:153). Ancak, yönetici ve çalışanlar arasinda etkin iletişimin olduğu, hedefleri net olarak belirlenmiş ve hantal bürokratik süreçlerden arınmış olan kamu örgütlerinin, hizmetlerin etkinliğini artırma ve vatandaş- 
lara karşı sorumluluklarını daha iyi yerine getirme amacıyla gerektiği zaman risk alma eğiliminde oldukları gözlenmektedir (Bozeman ve Kingsley, 1998:110).

\section{Kamu Örgütlerinde Yenilikçilik}

Yenilikçilik yeni fikir ve davranışların edinimi, gelişimi veya uygulanmasıyla ilintili bir süreç olarak örgüt içinde gelişen yeni bir fikrin ya da buluşun pazarlanabilir bir ürüne dönüştürülmesidir (Bulut, 2008: 1402). Yenilikçi bir girişimciden beklenen, alışılagelmiş karar alma kalıpları dışına çıkarak ürün ve pazar eşleşmesinde yeni yaklaşımlar geliştirme, belli düzeyde risk alma ve aldığ 1 bu riskin organizasyonel yapıda ve üretim mekanizmalarında ortaya çıkardı ğ 1 "yaratıcı yıkım" sürecini en iyi şekilde yönetebilmektir (Sadler, 2000: 27) ${ }^{1}$. Peter Drucker'ın ifadesiyle girişimciyi değişimi her zaman arayan ve en iyi sezinleyen kişi olarak kabul ettiğimizde; yenilikçiliğin, rastlantılar üzerine değil, bilinçli kararlar ve bilinçli adımlar üzerine kurulu bir yaklaşım olduğu görülmektedir (1985:21-25).

Kamu sektöründe yenilikçiliğin yeri üzerine yapılan çalışmalar; sosyolojik, teknolojik, ekonomik ve demografik alanlardaki değişimlerin kaçınılmaz bir sonuç olarak kamu örgütlerinde de yaşanmakta olduğunu ortaya koymuştur (Drucker, 1985: 143145; Holzer ve Callahan, 1998:4-7; Moon ve deLeon, 2001:328). Kamu örgütlerinde mevcut kaynak ve sistemleri daha önce denenmemiş bir biçimde yeniden tanımlamak suretiyle yeni hizmet sunumu ve yönetim anlayışlarının ortaya konulabileceği savunulmaktadir (Morris ve Kuratko, 2007:12; Kim, 2010:6). Bu perspektife göre yenilikçilik için gerekli esneklik ve seri hareket alanının önündeki kurumsal engelleri kaldırabilen, örgüt içinde girişimci bir at- mosfer oluşturabilen ve girişimci projelerin hayata geçirilmesine uygun bir sistemi adapte edebilen kamu kurumlarının hizmet üretim ve sunumunda daha etkin olması beklenmektedir (Kim, 2010:21). Bu duruma örnek olarak kırsal yerleşim yerlerinde mevcut sağlık hizmetlerindeki kısıtı aşmak veya kronik hastaların kendi meskenlerinde tedavi olmalarına olanak sağlayan tele tıp (telemedicine) sağlık hizmeti gösterilebilir. Tele tıp telefon, internet ve GSM gibi ağların kullanılarak uzaktan bilgi iletişimi ile hem konsultasyon bazinda hem de tanı ve uyarlabildiği ölçüde ameliyat robotu kullanımı ile cerrahi müdehaleleirn yapılabildiği tıbbi süreçlerdir. Bu uygulamanın doğru kullanıldığ durumlarda sağlık hizmetleri anlamında az gelişmiş bölgelere gerekli hizmetlerin akışını sağlamanın yanında, sağlık hizmetlerinde maliyetlerin düşürülmesi ve kalitenin arttırılmasına yüksek katkı sağladığı gözlenmiştir (Mack vd., 2008: 240) .

\section{Kamu Örgütlerinde Proaktivite}

Proaktivite, "değişim ve uyumdan farklı olarak, belirli hedefler doğrultusunda yeni bir oluşumu meydana getirme, yönetme ve hatta sonlandırma faaliyetlerine öncülük etme tutum ve davranışlarını ifade etmektedir" (Bulut vd., 1406). Dinamik bir yapiy1 ifade eden proaktivite, niteliği itibariyle kamu ve özel sektör örgütlerinde açı farklilıklar göstermemektedir. Hizmet sunumu ve yaratıcı çözüm üretme konularında sürekli arayışta olmanın yanında; değişimi sağlayıcı inisiyatife sahip olan, değişimi başarıyla hayata geçirebilen, ortaya çıkan fırsatları zamanında değerlendirme adına kaynakları en uygun şekilde kullanabilen kamu kurumlarının proaktif niteliklere sahip olduğundan söz edilebilir. Bürokratik anlayışla kurulmuş geleneksel kamu örgüt-

1 Yartıcı yıkım Avusturalyalı iktisatçı ve siyaset bilimci Joseph Schumpeter (1966) tarafından ortaya atılan bir tez olarak teknolojik yeniliklerin kapitalist ekonomilerde rekabtçi üstünlüğe ve dolayısyla ekonomik büyümeye katkı sağladığı şeklinde ifade edilebilir. Girişimcilik bağlamında bu tez, yeni ürün ve süreçlerin eskilerin yerini almasıyla başlayan ve zamanla yeniden yapılanma sürecinde tüm ekonomik akışlara nüfuz ederek sistemik bir çöküşe yol açması ve yapısal bir dönüşüme neden olması olarak anlaşılabilir. Dolayısyla, kesintisiz yenilik paradigma dönüşümünün derin taşıyıcısıdır. 
leri yönetsel ve politik denetimi önceleyen durağan ve yavaş işleyen bir niteliğine sahipken; girişimci kamu örgütleri proaktif yaklaşımın gereği olarak henüz oluşmamış sorun ve beklentileri önceden tespit ederek zamanında ve kaliteli hizmet üretimine dönük stratejiler geliştiren örgütlerdir. Proaktif kamu kurumlarının yenilikçi fikirlerin gelişimi için örgüt içi şartları oluşturdukları ve yakalanan fırsatları en iyi şekilde değerlendirebilmek için gereken kaynakları temin ettikleri tespit edilmiştir (Kim, 2010:26).

Kamu sektöründeki girişimcilik davranışlarının oluşum ve gelişiminde, özel sektör örgütlerinden farklı olarak yasal, yönetimsel ve politik yapiların etkileri oldukça yüksektir. Bu nedenle kamu kurumlarında girişimciliğin, bireysel kalite ve motivasyonlar yolu ile değil; örgüt içerisinde değişim, gelişim ve yenilik arzulayan bir grubun proaktif tutumlarıyla gelişebileceği kabul edilmektedir (Forster vd., 1996:11-12). Bu bakımdan kamu örgütlerinde girişimcilik söz konusu olduğunda, orta kademe yöneticilerinin yenilikçilik ve yaratıcılık konusunda proaktif bir rol üstlendikleri gözlenmektedir. Üst kademe yöneticileri (liderler) ise, örgütlerin geleceğini ilgilendiren girişimler konusunda öncelikleri tespit etme; yenilikçilik, proaktivite ve gerekli düzeyde risk alma boyutlarıyla oluşan girişimcilik süreçlerinin örgütsel değer ve standartlarını belirlemede öne çıkmaktadır (Bernier ve Hafs1, 2007: 483-494).

\section{Kamu Örgütlerinin Yapısal, Yönetsel ve Kültürel Karakteristikleri ve Girişimcilik}

Girişimciliğin kamu yönetimindeki yeri konusunda literatürde fikir ayrılıkları vardır. Kamu yönetimi çalışan yazarları fikir ayrılığına düşüren nedenlerin başında, kamu örgütlerinin hizmetlerinde kamu yararını ön planda tutmaları, kar amacı gütmemeleri ve kamusal kaynakları yerinde kullandıklarına dair sürekli olarak politik ve yasal denetim altında olmaları gerçeği gelmektedir (Bernier ve Hafsi, 2007: 488). Demokratik sistemlerde kamu görevlilerinden bilgi ve becerilerini, yürütmenin biçimlediği örgütsel yapı ve mekanizma içinde, yasama organları tarafından alınan kararlar çerçevesinde ve kamu yararı adına kullanmaları beklenmektedir (Eryılmaz, 2010: 610). Kamu sektöründe girişimcilik kavramına mesafeli tutumların altında, kamu örgütlerinin hareket alanlarını belirleyen eşitlik, hesap verilebilirlik ve kamu kaynaklarının doğru yönetimi gibi önemli kıstaslar ile risk almayı öneren 'girişimcilik' gibi bir anlayışın harmanlanması konusunda taşıdıkları kaygı olduğu kabul edilmektedir (Bernier ve Hafsı, 2007:488-489).

\subsection{Kamu Örgütlerinin Yapısal Karakteris- tikleri ve Girişimcilik}

Örgütlerin yapısal nitelikleri; hizmet planlama, geliştirme, üretip sunma mekanizma ve tarzları ile doğrudan ilişkilidir. Kurumların bürokratik örgütsel yapıda biçimlendiği geleneksel kamu sektörü örgütlerinde; hizmet üretim ve sunumunda hata payını düşük tutan, birimler arasında uyum ve kontrolü ön plana çıkartan, hiyerarşik disiplinin hakim olduğu bir işleyiş modeli göze çarpmaktadır. Örgütsel bağlamda girişimcilik kavramına geleneksel kamu kurumları ölçeğinde ele aldığımızda; risk alma, yenilikçilik ve proaktivite şeklinde üç boyutlu bir olgu olarak tanımladığımız girişimcilik uygulamalarının karşılaşacakları engelleri; örgütsel hiyerarşi, biçimsellik ve katılık olarak tespit edebilmemiz mümkündür (Moon, 1999: 33-34; Morris and Jone, 1999:76-77; Sadler, 2000: 29-30; Kearney, Hisrich ve Roche, 2009: 31-32; Kim, 2010:8). ${ }^{2}$ Kamu örgütlerinde girşimci süreçlerin gelişim ve yaygınlaşmasının önündeki örgütsel yapıdaki yüksek hiyerarşi ve biçimsellik ile yetki dağılımındaki sınırlamaların olası etkileri takip eden alt başlıklarda sırasıyla irdelenmiştir.

2 Kamu sektörü örgütlerinde bürokratik örgütlenmenin tüm unsurlarını irdelemek için bkz. Eryılmaz, 2010:214-220; Ergun ve Polatoğlu, 1988:60; Tompkins, 2005:41-52) 


\subsubsection{Hiyerarșik Örgüt Șeması}

Örgütlerin sahip olduğu otorite katmanlarının oluşturduğu kademe dizini olarak nitelendirilen hiyerarşik örgüt biçimlemesinde, bir alt kademedeki her görevli bir üst kademedekinin denetim ve gözetimi altındadır. Söz konusu denetim ve gözetimin yoğunluğu, örgüt içinde otorite/yetki katmanlarının sıklığıyla doğrudan ilişkilidir. İdeal bürokratik yapılardaki yetki alanları dikey bir yapılanmayı öngörür ve bu yapılanmada her kamu görevlisinin etki alanları belirgin şekilde bir alt ve bir üst otorite katmanı ile sınırlanmıştır. Bu nedenle, Moon (1999, s. 33) tarafından da belirttiği gibi, dikey hiyerarşik yapılanma özelliği gösteren çoğu örgüt daha çok mevcut durumu devam ettirme eğiliminde olurken, değişim ve yeniliği sağlayıcı nitelikteki bir esnekliğe ve örgüt içi aktif iletişim manevralarını gerçekleştirecek bir akışkanlığa sahip değildir.

Yüksek düzeyde hiyerarşik yapılar, kurum içi faaliyetlerde belirgin bir yavaşlamaya, iletişimde ciddi gecikmelere ve zamanla kapalı bir sistemin gelişimine sebebiyet verebilmektedir. Dolayısıyla, yüksek düzeyde hiyerarşik mekanizma üzerine kurulu örgütler (daha az hiyerarşik olan veya hiç olmayan örgütlere göre) daha az yenilikçi, risk içeren uygulama ve anlayışlara daha uzak duran, üretim ve hizmet geliştirmede (sorunlar oluşmadan ve firsatlar kaçmadan) proaktif adımların atılmasına müsait olmayan bir yapıya sahiptirler (Morris and Jone, 1999:79; Sadler, 2000: 37; Kearney, Hisrich ve Roche, 2009: 36; Kim, 2010:9). Sonuç olarak, üstlerin astlarını sürekli olarak denetim ve kontrol altında tutmasinı esas alan yüksek hiyerarşik örgüt yapısına sahip kamu kurumlarının risk alma, yenilikçilik ve proaktif eğilimlere kurumsal girișimcilik anlamında daha az elverişli oldukları kabul edilmektedir.

\subsection{2. Örgütsel Biçimsellik}

Biçimsellik karar verme davranışlarını etkileyen kurallar ve prosedürler bütünüdür.
Bir örgütün işleyiş yapısını, üyelerinin görev tanımlarını, yetki alanlarını ve faaliyetlerini yazılı kurallarla şekillendirme derecesi, o örgütün biçimsellik seviyesini belirlemektedir. Biçimciliğin yüksek derecede olduğu örgütlerde, örgüt üyelerinden beklentiler net olarak belirlenmiş olmakla birlikte; örgüt içi kontrolü arttırmak, belirlenen hedefler üzerindeki muğlaklığı en aza indirmek ve dolayısiyla hedeflerde sapmaya ya da gecikmeye yol açacak sürpriz gelişmeleri en aza indirmek amaçlanmaktadır (Tompkins, 2005: 166). Geleneksel kamu kurumlarında biçimselliğin yoğun olduğu gerçeğinden hareketle, kamu görevlilerinin mensup oldukları örgütlerin yazılı kuralları yanında, tüm örgüt mensuplarınca kabul görmüş tutum ve iş görme kalıplarına (teamüllere) kendilerini uydurmaları beklenmektedir. Biçimciliğin ön planda olduğu bürokratik örgüt tipinin kamu sektöründe oldukça yaygın olmasının bir diğer nedeni, kamu görevlilerinin keyfi tutum sergilemelerinin önüne geçmek; kişiye değil büroya (örgüte) ve büronun amaçlarına göre önceden düzenlenmiş objektif ve genel kuralları ön planda tutmaktır (Eryılmaz, 2010: 218).

Girişimcilik açısından bakıldığında, yüksek derece biçimciliğin hakim olduğu kamu örgütlerinin risk taşıyan karar ve uygulamalara elverişli, işleyiş ve hizmet sunumu adına yenilikçiliğe açık, kaynak kullanımı ve yönetiminde proaktif bir örgütsel ortama sahip olmaları uzak bir ihtimaldir. Bu örgütlerde kamu görevlilerinin örgüt amaçlarına ulaşmak adına dahi olsa risk almaları ve mensubu olduğu örgütün yazılı olan ve olmayan kurallarının şekillendirdiği hareket alanı dışına çıkmaları neredeyse mümkün değildir.

Mensubu oldukları kamu örgütlerinin kaynak kullanımını, işleyiş sistemini, ürün ve hizmet kalitesini örgüt hedefleri doğrultusunda yenilemek ya da geliştirmek isteyen kamu görevlileri çoğunlukla motivasyonlarını düşürecek düzeyde örgüt içi mecburi dokümantasyon sistemi (bilgi verme, onay alma, kaynak tahsisi için siyasi ve idari izin- 
ler vb) ile karşı karşıya kalma olasıkları yüksek olacaktır. Proaktif yaklaşımlar açısından bakıldığında ise, kamu yöneticilerinin tespit ettikleri olası sorunları ve bu sorunlara karşı ürettikleri çözüm önerilerini biçimciliğin öne çıktığ 1 ve yetki alanlarının kesin çizgilerle belirlenmiş olduğu kamu örgütlerinde uygulama imkanlarının az olduğu kabul edilmektedir (Morris and Jone, 1999: 76-77; Moon, 1999: 34; Sadler, 2000: 37; Boyne, 2002: 101).

\subsubsection{Sınırlı Yetki Alanı}

Geleneksel hiyerarşik ve bürokratik örgüt modelini benimsemiş kamu örgütlerinin karar alma ve uygulamada üyelerine sinirlı yetkiler sunduğu gözlenmektedir. "Bürokratik örgütlerde amaçların gerçekleştirilebilmesi için gerekli düzenli çalışmalar, resmi görevler olarak belirli bir biçimde dağıtılır. Bu görevlerin yerine getirilmesi için gerekli emir ve yaptırımlar kurallara bağlanır" (Eryılmaz, 2010: 217). Görevlerin düzenliliği ve sürekliliği, yetkilerin kullanılması, sistematik hükümlerle sağlanır. Kamu yöneticilerine karar almalarında ve uygulamalarında özel sektör yöneticileri kadar esneklik tanındığ1 takdirde, bireysel düzeyde alınacak riskli kararlar sonucu oluşan başarısız sonuçların maliyeti ilgili kamu yöneticisi veya kurumunun sorumluluğunda olmakla birlikte, kamu kaynaklarının yerinde kullanılmaması nedeniyle oluşan zarar kamusal sorumluluk haline gelmiş olacaktır (Dobell, 1989:2). Kamu kaynaklarının keyfi kullanımının önüne geçilmesi için kamu yöneticilerinin aldıkları kararlar ve attıkları tüm adımlar üzerinde üst yönetim kademesinin sürekli ve detaylı bir kontrolü söz konusudur. Kamu örgütlerindeki bu sinırlı yetki alanları ve yoğun hiyerarşik kontrol, yenilikçi adımları sınırlamasının yanında, riskten kaçınma kültürünün örgüt genelinde hakim olmasına da yol açmaktadır (Bozeman ve Kingsley, 1998: 112; Moon, 1999:34; Sadler, 2000: 131; Ott ve Goodman, 1998: 524).

\section{2. Кати Örgütlerinin Yönetsel Karakte- ristikleri ve Girişimcilik}

Örgütler yönetim yapıları ve işleyişleri itibariyle temel amaçlarına uygun olarak değişik karakteristiklere sahip olabilmektedir. Örgüt üyelerinin ürün ve hizmet sunumunda karar alma sürecine dahil edilmesi, üretilen hizmetin verim ve kalitesini ölçme ve değerlendirme faaliyetleri, bireysel ve takım düzeyinde performansların değerlendirmesi ve ödüllendirme mekanizmalarının örgüt hedeflerine ulaşmada etkin kullanılması gibi yöntemlerin günümüz özel sektör örgütlerinde yaygın olarak kullanıldığı görülmektedir. Kamu örgütlerinde uzmanlaşmaya verilen önem ve iş bölümü nedeniyle özel sektöre göre daha dikey bir örgüt yapılanması söz konusudur. Bunun yanında kamu örgütleri kamu kaynaklarını ve gücünü kullanarak hizmet üretim ve sunumunu gerçekleştirdikleri için tüm icraatları hakkında kamuya hesap verme yükümlülüğü altındadır.

Hiç kuşkusuz kamu örgütlerinin yasal düzenleme ve kurallarla şekillenen örgüt yapıları özel sektör örgütlerinden ayrışan yönetsel karakteristikleri beraberinde getirmektedir. Dolayısyla, kamu sektöründe girişimcilik süreçlerinin kapsamını ve sınırlılıklarını anlamada örgütlerin karar alma ve katılım süreçleri, sahip oldukları yetkinin s1nırları, çalışanlarından beklenen uzmanlaşmanın yanında tabi oldukları denetim mekanizmaları çalışmanın takip eden alt başlıklarında sırasıyla irdelenmiştir.

\subsubsection{Karar Alma ve Katılım Süreci}

Yönetsel mekanizmaları mekanik ve organik yönetim sistemleri olarak iki ana kategoriye ayıran Burns ve Stalker (1961), bürokratik model üzerine kurulmuş olan mekanik yönetim sistemlerini, dar çerçeveli, yüksek uzmanlaşmaya dayalı, görev tanım ve sorumlulukları net olarak belirlenmekle birlikte, üstlerin rutin dişı durumlarda doğrudan yönlendirmeye gittikleri, örgütsel iletişimin daha çok yatay olarak gerçekleştiği, birbirine eklemlenmiş otorite alanlarının bu- 
lunduğu örgütsel yapılar olarak tanımlamışlardır. Organik yönetim sistemleri ise, örgüt üyelerinin geniş ve esnek olan görev tanımları sayesinde bilgi ve tecrübelerini örgütün genel hedeflerine ulaşmak üzere kullanabildikleri, tüm kademeler ve tüm üyeler arasında etkin iletişimin sağlandığı, üyelerinin uzmanlık alanlarınin ve yetkilerinin yazılı iş tanımlarıyla sinırlandırılmadığ yönetim sistemleridir (Tompkins, 2005: 253). Yönetim tarzının örgüt hedeflerine göre şekillendirilmesinde, örgütlerin karar alma mekanizmaları ve bu mekanizmalara değişik konumlardaki örgüt üyelerinin katılım düzeyleri belirleyici öneme sahiptir. Girişimci düşünce ve yaklaşımların, örgüt içinde yeterli etkinliğe sahip olabilmesi, farklı konumdaki örgüt üyelerinin karar alma mekanizmalarına katılım düzeyiyle doğrudan ilişkilidir. Özellikle orta ve alt kademe çalışanlar tarafından geliștirilen, örgüt hedeflerine uygun yaratıcı ve yenilikçi fikirlerinin, üst yönetim birimlerince fark edilmesine fırsat tanıyan katılımcı karar alma mekanizmalarına sahip organik yönetimi benimseyen örgütler, girişimci yaklaşım ve uygulamalara daha yatkın bir yapı arzederler (Andrew, Boyne ve Walker, 2007: 58-62).

Son yıllarda stratejik planlama, stratejik yönetim, performansa dayalı yönetim ve toplam kalite yönetimi gibi katılımcı karar alma mekanizmaları üzerine temellendirilmiş yönetim tekniklerinin, özel sektörde olduğu gibi kamu sektörü örgütlerinde de başarılı sonuçlar doğuracakları yönünde bir beklenti oluşmuştur. Ancak klasik kamu yönetiminin merkeziyetçi anlayışla çizdiği katı görev ve yetki kalıplarıyla oluşan hiyerarşik yapılarda, kamu örgütlerinde alınan kararlara doğrudan ve etkin katılımdan söz edilememektedir. Geleneksel kamu örgütleri, kamu görevlilerinin uzmanlık alanları dışına taşacak karar alma imkanlarını düşük düzeyde tutmak için, üst makamlar hiyerarşik kontrolü baskın bir şekilde kullanmaktadırlar (Bozeman ve Kingsley, 1998: 110; Ott ve Goodman, 1998: 525-527; Kim, 2010: 10). Eryılmaz'ın (2010) da ifade ettiği gibi, kamu kuruluşlarında üstlerin hiyerarşik denetim vasıtasıyla astların işlemlerini onaylama, geciktirme ve hatta iptal etme yetkileri, yazılı idari düzenlemelere dayalı olmadığ lerde bile mevcuttur (s. 316). Bu nedenle, kamu örgütlerinin hiyerarşik yönetim yap1ları, her kademedeki örgüt üyesinin karar alma mekanizmalarına katılımını sağlayacak şekilde esnekleştirilmediği sürece; kamu görevlilerinin yaratıcı, yenilikçi ve proaktif düşüncelerini diğer örgüt üyeleri ve özellikle üst yönetim kademesi ile paylaşabilme ihtimali özel sektör örgütlerine oranla daha düşüktür.

\subsubsection{Yönetsel Özerklik}

Kimi örgütler, üyelerine karar alma ve bu kararları hayata geçirmede daha özgür yönetsel ortamlar sunabilmekte ve üyelerinin karar ve faaliyetlerinin denetimini doğrudan hiyerarşik üstlerinin inisiyatifine bırakmamaktadır. Örgüt üyelerinin görev ve sorumluluklarını yerine getirirken, örgüt hedeflerine ulaşmak adına kararlar alma, fikir üretme, geliştirme ve uygulama konusunda daha geniş yetkiler ile donatılmasına özerklik denilmektedir (Lumpkin ve Dess, 2001: 432). Bir örgütün hedeflerine ulaşmasında, genel işleyişinde ve başarısında farklı ölçülerde katkıları olan bölümlerin veya takımların, kendi başlarına aldıkları kararları hayata geçirmek için örgütün kaynaklarını diledikleri gibi kullanma ayrıcalıkları yoktur. Örneğin, özel sektör örgütlerinde yönetim kademelerinin ve örgüt üyelerinin yönetsel özerkliği, örgütün temel hedefi olan "karlılık" düzeyini arttırabildikleri, sektörel rekabet avantajını güçlendirici stratejileri hayata geçirebildikleri oranda söz konusu olabilmektedir (Boyne, 2002:101). Kamu örgütlerinde ise, görev ve yetki kullanımında üst birimlerinin sürekli kontrol, denetim ve onayına tabi olan yönetici ve üyelerin, görevlerini yerine getirirken kullandıkları kaynak ve yetkilerin "kamusal" niteliğe sahip olması, onların daha temkinli olmalarını gerektirmektedir (Eryılmaz, 2010: 50-51).

Kamu örgütlerinde yönetsel özerklik incelendiğinde, örgüt dışı yasal ve politik de- 
netimle örgüt içi hiyerarşik ve profesyonel denetimin şekillendirdiği sorumluluk alanı çerçevesinde sınırlı bir özerklikten bahsedilebileceği kabul edilmektedir (Ergün ve Polatoğlu, 1988: 518; Ackroyd, Hughes ve Soothill, 1989: 606; Lynn, 1996: 147-148; Romzek, 2000: 608). Özel sektör örgütlerine nazaran kamu görevlilerine daha dar bir özerklik alanı tanınması, mevcut durum d1şına çıkılarak yenilik ve değişimi getirecek girişimci adım ve yaklaşımların kamu sektörü örgütlerinde gözlenme olasılığını düşürmektedir. Ancak sinırlı özerklik söz konusu olsa da, kimi kamu kurumlarının sadece etkin kaynak dağılımı ve kullanımına imkan veren özgür karar alma süreçleri sayesinde daha verimli hizmet üretimi ve sunumuna ulaştıkları; risk alma, yenilikçi ve proaktif adımların şekillendirdiği girişimci eğilimlerin daha rahat ortaya çıktığ edilmektedir (Bozeman ve Kingsley, 1998: 114; Ramamurti, 1986: 152-156; Dennis, Langley ve Rouleau, 2005: 460-462).

\section{2.3. Kamu Örgütlerinde Uzmanlașma}

Örgüt yönetici ve üyelerinin uzmanlık düzeyleri, görev ve sorumluluk alanlarının gerektirdiği profesyonellik ve ihtisaslaşma kapasiteleri çerçevesinde değerlendirilmektedir. Yüksek uzmanlaşmanın gözlendiği örgütlerde, üyelerin sahip olduğu profesyonellik ve teknik uzmanlık seviyeleri doğrultusunda öngörülen işbölümü ile örgüt hedeflerine ulaşmada kaynakların daha etkin kullanılması amaçlanmaktadır (Moon, 1999: 34). Klasik kamu örgütlerinde ise örgüt üyelerinin hiyerarşik örgüt düzeni çerçevesinde oluşan işbölümüyle, genel hatları çizilmiş faaliyet alanlarında yeterli uzmanlık düzeyine sahip olmaları beklenmektedir (Martinez ve Richardson, 2008: 84; Ery1lmaz, 2010: 218). Uzmanlaşma sürecinde formel anlamda hizmet içi eğitimden, enformel anlamda ise tecrübeli örgüt üyelerinin yeni üyelere deneyimlerini aktarmalarını teşvik edici mekanizmalardan faydalanılmaktadır.

İşbölümüne dayalı yüksek uzmanlaşmanın yaygın olduğu geleneksel kamu örgüt- leri girişimci faaliyetler bakımından ele alındığında, yenilikçi yaklaşımların ortaya çıkması adına olumlu; risk alma ve proaktif yaklaşımların sergilenmesi anlamında ise olumsuz sonuçlar tespit edilmiştir. Alanlarında uzmanlaşmış kamu görevlileri, yüksek teknik ve becerilere sahip olmalarından dolayı, kamu hizmetlerinin etkinliğini arttırma amacı doğrultusunda yenilikçi faaliyetlerde bulunabilecek yeterliliğe sahiptirler (Sadler, 2000: 36, Kim, 2010:20-22). Bu nitelikteki kamu görevlilerinin, sahip oldukları profesyonel bilgi ve teknik uzmanlık kapasitelerinden dolayı, örgüt hedefleri doğrultusunda performans ve verimliliği arttırıcı yeni mekanizmalar geliştirme ve uygulamaya sokma gibi yenilikçi bir eğilime yatkın oldukları da kabul edilir. Ancak katı hiyerarşik kontrol ve denetim mekanizmalarının, görev alanları itibariyle uzmanlaşmış kamu yönetici ve görevlilerinin proaktif açılımlarda bulunma temayüllerini törpülediği de bilinen bir gerçektir (Moon, 1999: 34).

\subsubsection{Kamu Sektöründe Hesap Verme Yükümlülüğü}

Örgütler, görevlerini yerine getirirken kullandıkları kaynak ve yetkileri ile sergiledikleri performans açısından üyelerini denetime tabi tutarlar. $\mathrm{Bu}$ denetim hedeflere ulaşmada etkinlik ve verimlilik, yönetim prensiplerine sadakat açısından ise yerindelik denetimi şeklindedir. Özel sektör örgütlerinin performans ölçme ve değerlendirme sistemlerinde temel kıstas, çalışanların örgütün karlılık kapasitelerine yaptıkları katkı düzeyidir. Buna karşın kamu yöneticileri ve çalışanları için aynı şeyi söylemek mümkün değildir. Kamu çalışanları, görevlerini yürütürlerken kamu kaynaklarını en etkin biçimde kullanma sorumluluğu taşırlar. Bunun yanında hizmet sunumunda eşitlik ve adalet gibi prensiplere uygun icraatlarda bulunma yükümlülükleri de söz konusudur. Kamu kuruluşları, özel sektördeki benzer örgütlerde görüldüğü gibi belli bir birimin değil, kamusal kaynak ve yetkileri kullanmaları cihetiyle bağlı oldukları üst yürütme 
organinin, yasama ve yarg1 organlarinin doğrudan yada dolaylı denetim ve gözetimi altında faaliyetlerini sürdürmektedirler (Ergün ve Polatoğlu, 1988 :9). Kamu yönetici ve görevlilerinin hesap verme yükümlüğünün boyutlarını belirleyen bu çok yönlü denetim Tablo 1'de görsel olarak sunulmuştur.

\section{Tablo 1}

Kamu Örgütlerinde Denetim ve Denetimin Boyutları

\begin{tabular}{|c|c|c|c|}
\hline & \multicolumn{2}{|c|}{$\begin{array}{c}\text { Beklenti ve/veya Denetim } \\
\text { Kaynakları }\end{array}$} \\
\hline & & Örgüt İçi & Örgüt Dışı \\
\hline \multirow[t]{2}{*}{$\begin{array}{l}\text { Özerklik } \\
\text { Derecesi }\end{array}$} & Düşük & Hiyerarşik & Yasal \\
\hline & Yüksek & Profesyonel & Siyasal \\
\hline
\end{tabular}

Kaynak: Romzek, 2000: 24.

Kamu görevi ifa eden bireylerin ve örgütlerin çok yönlü bir hesap verme yükümlülüğü altında olduklarını gösteren yukarıdaki tablonun vurguladığı gibi, kamu örgütleri icraatları bakımından sahip oldukları özerklik statüsüne bağlı olarak belirlenen iç (hiyerarşik ve profesyonel) ve diş (yasal ve siyasal) denetim mekanizmalarına tabi tutulmaktadırlar. Romzek'e göre demokratik kamu yönetimi sistemlerinin, kamu görevlileri üzerinde (çalıştıkları kurumların sahip oldukları özerkliğin sağladığı yönetsel ve yasal esneklikler göz önüne alındığında) hiyerarşik, yasal, profesyonel ve siyasal mekanizmaların kullanıldığ 1 dört denetim tipi mevcuttur (2000: 24-25).

Tablo 1'de kesik çizgilerle ifade edilmeye çalışıldığ 1 üzere, kamu yöneticileri bir denetim ağ 1 içerisinde görevlerini yerine getirme durumunda olmakla birlikte; hiyerarşik, yasal, profesyonel ve siyasi aktörlerin farklı beklentilerine uygun olarak hizmet geliştirme ve sunma yükümlülügüu altındadırlar.
Dolayısıyla kamu görevlileri, hiyerarşik açıdan hesap verme anlamında üstleri tarafından "etkinlik" denetimine; yasal açıdan hesap verme anlaminda (yasalar ve yarg1 kararları bağlamında) "hukuka uygunluk" denetimine; profesyonel açıdan hesap verme anlamında (atandikları pozisyonun gerektirdiği) "uzmanlık" denetimine; ve siyasi aç1dan hesap verme anlaminda (kamu gücü ve kaynaklarını kullanan ve özellikle seçilmiş kamu görevlilerinin), seçmenlerin beklentilerine "cevap verme" denetimine tabi oldukları gözlemlenmektedir (Romzek, 2000: 28-31).

Çok yönlü bir denetim ağıyla örülmüş kamu örgütlerinde, kamu görevlilerinin yetki alanları ve performansları üzerindeki örgüt içi denetim mekanizmalarının, girişimci yaklaşım ve faaliyetlerin gelişimine etkisi vardır. Hiyerarşik açıdan hesap verme, kamu gücünü ve kamu kaynaklarını kullanımda istismarı önlemek amacıyla, hizmet üretimi ve sunumunda düşük derecede özerklik öngören, ast-üst ilişkilerinin belirgin hatlarla çizildiği ve astların periyodik olarak üstler tarafından yetki kullanımları ve sergiledikleri performans açısından kontrol altında tutulduğu kamu örgütlerinde yaygın bir şekilde kullanılmaktadır. Hiyerarşik açıdan hesap verme bağlamında kamu örgütlerinin girișimci yaklaşım ve faaliyetlere ne kadar açık olduğunu, hizmet üretim ve sunumunda kamu görevlilerine tanınan "takdir" hakkına örgüt dişı (yasal ve siyasal) denetim mekanizmalarınca hangi düzeyde müsaade edildiği önemli bir noktadır. Örneğin, Türkiye'de "Bağımsız İdari Otoriteler" şeklinde tasnif edilmiş olan özerk kamu örgütleri dışında, kamu örgütlerinin büyük çoğunluğunun hiyerarşik (örgüt içi), yasal ve siyasal (örgüt dışı) denetim mekanizmaları nedeniyle hizmet üretim ve sunumunda risk alma, yenilikçilik ve proaktivite gibi girişimci eğilimler büyük ölçüde sınırlayan yönetsel mekanizmalar mevcuttur.

\subsection{Kültürel Karakteristikler}

Yazılı bir metin şeklinde olmadığı halde 
en üst kademeden en alt kademeye kadar tüm örgüt üyelerinin hareket, tutum ve davranışlarını şekillendiren inanç, teamül, değer ve prensiplerin oluşturduğu kültürel karakteristikler, örgütlerin varoluş ve işleyişlerinde oldukça önemli bir role sahiptir. Örgüt kültürü bir örgütün üyelerince zaman içinde tecrübe edilerek karşılaşılan problemlerin aşılmasında, etkinliğin arttırılmasında ve hedeflere ulaşılmasında kullanilan yöntem, anlayış, düşünme ve tutumların oluşturduğu ve her yeni üyeye aktarılan temel usul, değer ve varsayımlar şeklinde tarif edilmektedir (Schein, 2010: 21).

Örgüt kültürünün temel öğeleri olarak kabul edilen örgüt üyelerinin değer yarg1ları, ahlaki yaklaşımları, inanç sistemleri, yönetsel teamülleri ve enformel iletişim yöntemleri, kamu ve özel sektör örgütlerinde farklı doku ve farklı yoğunlukta ortaya çıkar (Hill ve Lynn, 2009: 192). Girişimciliğin ön plana çıtığ 1 örgütlerin değer yaratma sürecinin yenilikçilik ile değişimi; bu bağlamda örgütsel bağlilık ile kişisel sorumluluğu ve gelecek odaklı bir anlayışı, örgütsel değer ve normlar çerçevesine oturtması beklenmektedir (Kim, 2010: 11). Hatta Morris ve Kuratko'ya göre (2002), girişimcilik adına etkin bir örgüt kültürünün, problemler yerine fırsatlara odaklanmış girişimci modele elverişli ve örgüt üyelerini kucaklay1c1 yapıda olması gerekmektedir (s. 22).

Kamu örgütlerinin geleneksel anlamda dikey örgütlenme modelini benimsemeleri ve yönetsel olarak hiyerarşik hesap verme sorumluluğu taşımaları; "riskten kaçınma" kültürünü yaygınlaştırıcı etkide bulunur (Sadler, 2000: 30 ve 38). Değerler sistemi ve yapısal özellikleri ile kamu örgütlerinin kültürel yapıları ele alındığında, girişimci yaklaşım ve faaliyetlerin oluşum ve gelişimine etki edebilecek nitelikte örgüte bağl1lık, motivasyon ve ödüllendirme gibi kavramların ön plana çıktığı görülmektedir. Bu nedenle, kamu örgütlerinde tüm örgüt üyelerinin sahip olduğu inanç, değer ve tutumların girişimci eğilimlerin şekillenmesine çok yönlü etkisi söz konusudur. Çalışmanın bu bölü- münde geleneksel kamu örgütlerinde mevcut olan temel güdüleyicilerin ve örgütsel hedeflerdeki belirsizlik durumlarının girişimci eğilimlere etkisi incelenecektir.

\subsubsection{Kamu Örgütlerinde Motivasyon ve} Örgüte Bağlılık

Çalışanların örgütlerine olan güçlü aidiyetlik hissi ve katılım bilinci olarak tanımlanan örgütsel bağlllık örgüt üyelerinin örgüt değerlerine ve hedeflerine olan güçlü inançları, örgüt için üst düzey performans sarf etmeye hazır olmaları ve örgütün kalıcı birer üyesi olma yönünde yüksek arzuları şeklinde ortaya çıkmaktadır (Crewson, 1997:507; Balfour ve Wechsler, 1996:257). Bugüne dek yapılan araştırmalarda kamu ve özel sektör örgütlerinde çalışanların bağlılık düzeyleri konusunda aralarında bariz bir fark gözlenmemektedir. Ancak örgüte aidiyet bilincinin yönetici ve çalışanlarda yerleşmesinde motivasyonel faktörlerin farklı etkileri olduğundan söz edilmektedir (Perry ve Wise, 1990: 370; Perry, 1996: 279-280; Moon, 1997: 179). Maddi ödüllendirmeye dayanmayan içsel güdüleyicilerin kamu sektörü örgütlerinde daha yaygın ve etkin olduğu gözlenmektedir. Kamu sektörü çalışanlarının kamu yararına hizmet üretimiyle, kamu politikalarının oluşum ve işleyiş sürecine sağladıkları katkılar ölçeğinde daha fazla performans ve iş tatminine sahip oldukları tespit edilmiştir. Ancak kısıtlı takdir yetkisine sahip olmaları gibi kamu örgütlerinin hiyerarşik ve katı örgüt yapılarından kaynaklanan kısıtlamaların iş tatmin düzeyleri üzerindeki olumsuz etkilerini de göz ard1 etmemek gerekir (Hal and Young, 2005; 86-94). Kamu örgütlerinde kamu hizmeti sunulurken, örgütün hedeflerini benimsemiş, yeterli yetkiyle donatılmış ve karar alma mekanizmalarına dahil edilmiş kamu yönetici ve çalışanlarının görevlerini daha azimli bir şekilde yerine getirmeleri beklenir. Böyle bir çalışma ortaminda oluşan ya da gelişen örgüt kültürünün, risk alma ve yenilikçi eğilimlerin gelişimi üzerine etkisi olduğu kabul edilmektedir (Moon, 2000: 185). 
Balfour ve Wechsler'in (1996; 270-272) gerçekleştirdiği araştırmanın gösterdiği üzere, katılım mekanizmalarının yaygınlığ ve işlerliği, siyasi aktör ve unsurların hizmet yönetimi ve sunumuna daha az müdahalede bulunduğu, üst düzey yöneticilerin destek ve olumlu telkinleri ve kamu yararına artı değer oluşturma isteğinin oluşmasına elverişli kamu örgütlerinde, çalışanların örgütlerine daha bağlı bireyler oldukları gözlenmiştir.

Sınırlı yetkilerle donatılmış, yetki ve hizmetlerde çoklu denetime tabi olan kamu görevlilerinin, geleneksel kamu örgütlerinde gözlenen örgüt kültürü içinde; risk alma, yenilikçilik ve proaktif faaliyetlerde bulunacakları bir manevra alanına sahip olmaları oldukça zor görünmektedir. Özellikle, politik aktörlerin hizmet yönetimi, üretimi ve sunum sürecine her zaman müdahil olabildiği, kamu yönetici ve çalışanlarının özgür karar alma ve yetki kullanma kapasitelerinin sınırlandığ1 kamu kurumlarında girişimci tutum ve faaliyetlere dönük olumlu bir atmosferin varlığından bahsedilmemektedir (Moon, 1999: 41; Balfour ve Wechsler, 1996: 271; Kim, 2010: 20).

\subsubsection{Kamu Örgütlerinde Belirsiz Hedefler}

Özel sektör örgütleri yüksek karlılık gibi tek ve rahatlıkla ölçülebilir bir hedefe sahipken, çoğu kamu kurumunun ölçülmesi oldukça zor ve muğlak hedeflere sahip olması söz konusudur. Yönetsel anlamda kamu örgütlerinin yer yer birbiriyle çelişen ve zaman içinde değişim gösterebilen hedefler doğrultusunda hizmet sunması söz konusudur. Bunun en önde gelen nedenlerinden birisi, cumhuriyet rejiminde seçilmiş ve atanmış kamu görevlileri tarafından yasama ve yürütme erkleri halk adına ve halk için kullanılması gelmektedir. Merkezi ve yerel yürütme organlarında etkin rol oynayan politikacılar ya da seçilmiş kamu görevlileri, kamu kurumlarının hedeflerini belirlerken genellikle yeniden seçilme kaygısıyla toplumun her kesimine hitap eden, vatandaşların farklı düzey ve yoğunluktaki taleplerine cevap verebilecek esneklikte bir politika iz- leme eğilimi içindedir. Haliyle, örgütsel politika ve hedeflerin geliştirilmesi sürecinde alaninda uzman ve belirli bir tecrübe elde etmiş kamu görevlilerinin faaliyetleri zaman zaman yürütmede etkin olan politikacılar tarafından yönlendirilmekte veya sinırland1rilmaktadır (Boyne, 2002: 101).

Ayrıca, merkezi ve yerel kamu kurumlarının sunduğu hizmetler, özel sektörün kar elde etme beklentisiyle arz ettiği ürün ve hizmetlerde olduğu gibi rakamsal değerlerle ifade edilemeyen ve dolayısıyla etkinlik düzeyleri her zaman ölçülemeyen kamusal ürün ve hizmetler niteliğindedir. Dolayısıyla yer yer birbiriyle çelișebilen ve ölçülmesi güç kurumsal hedeflere sahip geleneksel kamu sektörü örgütlerindeki mevcut örgüt kültürünün; risk alma, yenilikçilik ve proaktivite eğilimleri teşvik eden girişimci kültürün gelişmesi için daha az elverişli olduğu kabul edilmektedir (Bozeman ve Kignsley, 1998:115; Sadler, 2002: 38). Diğer yandan kamu örgütlerinin birçoğu her ne kadar birbiriyle çelişebilen hedeflere sahip olmak gibi bir durumla yüz yüze olsa da; kurumsal faaliyet ve işleyişlerinde bu hedefleri önceleme anlaminda uygulamada belirli bir takdir hakkına sahiptirler. Söz konusu takdir hakkı, seçilmiş kamu görevlilerinin ucu açık hedef ve politikalara uygun kamusal hizmet ve faaliyetlerinde belirli bir manevra alanı oluşturabilmektedir. Dolayısıyla, kurumsal girişimcilik açısından ele alındığında, söz konusu takdir hakkının hedef ve politikalara uygun faaliyetlerin planlama, yürütme ve sunumunda yenilikçi yaklaşımlara ve kamu kaynaklarını etkin kullanılması şartıyla orantılı risk alma eğilimlerine olanak sağlayacak bir örgütsel kültürün oluşmasına katk1 sağlayabileceği düşünülmektedir (Moon, 1999:34; Sadler, 2002: 38; Edwards, Jones, Lawton ve Llewelly, 2002: 1552; Kim, 2010 :23).

\section{Sonuç ve Değerlendirme}

Kamu örgütlerinin yapısal, yönetsel ve kültürel karakteristiklerine uygun olmak ve kamu hizmetlerinde eşitlik, süreklilik ve 
adalet prensipleriyle çatışmamak kaydıyla, daha kaliteli ve daha etkin hizmet sunumuna elverişli yeni kavramlara olan ihtiyaç gün geçtikçe daha belirgin hale gelmektedir. 1990'lardan bu yana yeni kamu yönetimi anlayışıyla tartışılmaya başlanan yeni kavramlardan birinin de girişimcilik kavramı olduğu görülmektedir. Neredeyse otuz yıla varan bir periotta yapılan akademik çalışmaların girişimcilik anlayışının özel sektör uygulamalarında gözlendiği gibi aynen kamu örgütlerine aktarılamayacağını ortaya koyarak, kamu örgütlerinin yapısal, yönetsel ve kültürel karakteristikleri çerçevesinde girişimciliğin bir süreç olarak ele alınması gerektiği ileri sürülmektedir. Özellikle gelişmiş ülke kamu yönetimi araştırmacılarının yoğun olarak inceledeği girişimcilik kavramı, Türkiye'de henüz üzerinde pek fazla durulan bir konu değildir. Bu çalışma ülkemizde kamu sektöründe girişimcilik konusunda yapılan sınırlı çalışmalara katkı ve ileriki yıllarda gerçekleştirilecek ampirik incelemelere altyapı sağlaması amacıyla yapılan bir çalışmadır. Çalışmamızda detaylı bir literatür taraması yapılarak, kamu sektöründe girişimciliğin bir süreç olarak temel öğeleri belirlenmiş ve geleneksel kamu örgütlerinin yapısal, yönetsel ve kültürel karakteristikleri bağlamında değerlendirmeler yapilmıştır.

Geleneksel kamu sektörü örgütlerinin hiyerarşik görev dağılımı ve yetki kullanıminda yüksek düzeyde gözlenen biçimciliği, kamu sektörü örgütlerinde kurumsal girişimcilik eğilim ve faaliyetleri anlaminda s1nırlayıc1 etkiye sahiptir. Öte yandan hiyerarşik yönetim yapılarında yeterli düzeyde özerkliğe ve uzman kamu görevlilerinin karar alma mekanizmalarına rahatlıkla katılımına izin veren kamu kurumlarının, kamu hizmetlerinde etkinliği arttırmaya dönük yenilikçi ve proaktif eğilimlere açık örgütler olduğu görülmektedir. Kamu örgütlerinin hesap verme sorumluluklarının özüne dokunulmaksızın; kullanılan denetim ve kontrol mekanizmalarının yenilikçi ve proaktif açılımlara müsaade edecek düzeyde kamu yararı ilkesi doğrultusunda ye- niden gözden geçirilmesi önem ihtiva etmektedir. Benzer şekilde, kamu sektörüne hakim olan örgüt kültürünün, girişimci yönetim ve oryantasyonun gelişmesindeki önemi büyüktür. Geleneksel kamu örgütlerinde gözlenen bürokratik kültür ve seçilmiş kamu görevlilerinin kurum politikalarının belirlenmesi sürecindeki pragmatik yaklaşımları kamu sektöründe girişimci eğilimleri törpülerken, uzmanlaşmış kamu görevlilerine kurumsal hedef ve politikaların belirlenmesinde tanınacak yüksek takdir yetkisi zamanla girişimci kültürün oluşmasına katkı sağlayacaktır.

$\mathrm{Bu}$ çalışmanın sunduğu analiz çerçevesinde bir süreç olarak girişimcilik kamu örgütlerinde belirgin kısıtlarla yüzyüzedir. Süz konusu kısıtlara rağmen risk alma, yenilikçilik ve proaktif süreçlerin kamu örgütlerinin temel karakteristiklerine uygun olarak dizayn edildiğini gösteren araştırmalar mevcuttur. Bu açıdan ele alındığında sunulan kamu hizmetinin türüne, hizmeti sunan örgütün büyüklüğüne, siyasal ve yönetsel denetim mekanizmalarının yoğunluğuna bağlı olarak gün geçtikçe daha fazla kamu örgütünün girişimci süreçlerle tanışmaktadır. Türkiye'de de kamu kaynaklarını yerinde kullanarak adil bir şekilde hizmet dağıtmakla yükümlü bir çok merkezi ve yerel yönetim örgütlerinin geleneksel kamu örgütü formatı dışına çıkarak yenilikçi ve proaktif tutum içinde vatandaşlara hizmet sunma çabasında olduğu görülmektedir. Gelecek araştırmaların, kamu örgütlerinde gözlenen girişimcilik örneklerini analiz ederek, başarilı süreçlerde etkin yapısal, yönetsel ve kültürel faktörleri tespit etmeye dönük çalışmalar olması beklenmektedir. 


\section{KAYNAKÇA}

Ackyord, S., Hughes, J.A. ve Soothill, K. (1989). Public Sector Services and Their Management. Journal of Management Studies, 26:6, ss. 603-619

Andrew, R., Boyne, G.A. , Law, J. ve Walker, R.,M. (2007). Centralization, Organizational Strategy, and Public Service Performance. Journal of Public Administration Research and Theory, Vol. 19, ss. 57-80

Bahran, G. (2002), Özerk Kurumlar Hakkında Rapor, T.C. Sayistay Baskanligi Arastirma Grubu, Ankara. http:/ /www.sayistay.gov.tr/yayin/ele k/elekicerik/36OzerkKurRap.pdf

Balfour, D. L. ve Wechsler, B. (1996). “Organizational Commitment: Antecendents and Outcomes in Public Organizations," Public Productivity and Management Review, Vol. 19, No. 3, ss. 256-277.

Bernier, L. ve Hafsi, T. (2007). "The Changing Nature of Public Entrepreneurship." Public Administration Reivew. Vol. 67, Issue 3, 488-503.

Borins, S. (1998). Innovating with Integrity: How Local Heroes are Transforming American Government. Georgetown University Press: Washington D.C. .

Boyett, I. (1997) “The Public Sector Entrepreneur: A Definition." International Journal of Entrepreneurial Beahviour and Reseacrh, Vol. 3 No. 2,ss. 77-92

Boyne, G. A. (2002). Public and Private Management: What's the Difference?. Journal of Management Studies, 39:1, ss. 97-122

Bozeman, B. ve Kingsley, G. (1998). "Risk Culture in Public and Private Organizations." Public Administration Review, Vol. 58, No.2, ss. 109-118
Bozeman, B., \& Kingsley, G. (1998). “Risk culture in public and private organizations." Public Administration Review, $58,109-117$.

Brockhaus, R. H. (1980). "Risk Taking Propensity of Entrepreneurs." Academy of Management Journal. 23 (3): 509-520.

Burns, T. ve Stalker, G.M. (1961). The Managament of Innovation. London: Tavistock Publication.

Bulut, Ç., Fiş, A.M., Aktan, B., Yılmaz, S. (2008). "Kurumsal Girişimcilik: Kavramsal Yapı Üzerine Bir Tartışma." Journal of Yaşar University, 3 (10), ss. 1389-1416.

Crewson, P. (1997). "Public Service Motivation: Building Emprical Evidence of Incidence and Effect." Journal of Public Administration Research and Theory, Vol. 7, ss. 499-518.

Currie, G., Humphreys, M., Üçbşaran, D., McManus, S. (2008). "Enterpreneurial Leadership in the English Public Sector: Paradox or Possibility?" Public Administration, Vol. 86, No. 4, ss.987-1008.

Damanpour, F., \& Schneider, M. (2009). "Characteristics of innovation and innovation adoption in public organizations: Assessing the role of managers." Journal of Public Administration Research and Theory, 19, 495-522.

Dennis, J., Langley, A., ve Rouleau, L.( 2005). Rethinking Leadership in Public Organizations. Ed. Ferlie, E., Lynn, L.E., Pollit, C., The Oxford Handbook of Public Management. New York: Oxford University Press, ss. 446-467.

Dobell, A.R. (1989). The Public Administrator: Good? or Entrepreneur? Or Are They the same in the Public Service. American Review of Public Administration, Vol. 19, No. 1, ss. 2-11. 
Drucker, P. F. (1985). Innovation and Entrepreneurship: Practice and Principles, Butterworth-Heinemann, London

Edwards, C., Jones, G., Lawton, A., Llewellyn, N.(2002)." Public Entreprenurship: Rhetoric, Reality, and Context." International Journal of Public Administration, Vol. 25, No. 12, ss. 1539-1554.

Eggers, W. D., \& O'Leary, J. (1995). Revolution at the roots: Making our government smaller, better, and closer to home. New York, NY: Free Press.

Ergun, T. ve Polatoğlu, A. (1988). Kamu Yönetimine Giriş, 3. yayım. Ankara: Türkiye ve Orta Doğu Amme İdaresi Enstitütüsü

Eryilmaz, B. (2010). Kamu Yonetimi: Dusunceler, Yapilar, Fonksiyonlar. 3. Baski. Sozkesen Matbaasi: Ankara.

Espinosa, M. dM. B., Suanes, A.M. (2011). "Corporate Entrepreneurship Through Joint Ventura." International Entrepreneuship Management, vol. 7, ss. 314430 .

Forster, J, Graham P. ve Wanna, J. (1996). "The New Public Entrepreneurialism." Ed. J. Wanna, J. Forster ve P. Graham. Entrepreneurial Management in the Public Sector. Macmillan: Melbourne.

Hal, G. R. ve Chun, Y. H. (2005). "Public and Private Management Compared", (ss.72-102)" Ed. Ewan Ferlie, Laurence E. Lynn ve Christopher Politt. The Oxford Handbook of Public Management. Oxford University Press Inc. : New York.

Hall, R.H. (1996). Organizations: Structures, Processes, and Outcomes. Englewood Cliffs, NJ: Prentice Hall.

Hill, C.J. ve Lynn, L.E. (2009). Public Management: A Tree-Dimensional Approach. Washington, D.C.: CQ Press.
Holzer, M., \& Callahan, K. (1998). Government at work: Best practices and model programs. Thousand Oaks, CA: Sage.

Kaboğlu, İ. (1998). Bağımsız İdari Otoriteler. İstanbul: Alkım Yayınevi.

Keh, H.T., Foo, M.D., Lim, B.C. (2002). “Opportunity Evaluation under Risky Conditipns: The Cognitive Processes of Entrepreneurs." Entrepreneurship Theory and Practice, winter, ss. 125-148.

Kearney, C., Hisrich, R.D., ve Roche F.,( 2009). "Public and Private Sector Entrepreneurship: Similarities, Differences or a Combination?" Journal of Small Business and Enterprise Development, Vol. 16, No.1, ss. 26-46

Low, Murray B. (2001). “The Adolescence of Entrepreneurship Research: Specification of Purpose." Entrepreneurship Theory and Practice, Summer, 17-25.

Lumpkin, G.T. ve Dess, Gregory G. (2001). "Linking Two Dimensions Of Entrepreneurial Orientation To Firm Performance: The Moderating Role Of Environment And Industry Life Cyle". Journal of Business Venturing, 16, 429451.

Lynn, L. E. (1996). Public Management As Art, Sciences, and Profession. Chatham, NJ: Chatham House Publishers.

Mack, W.R., Green, D., Vedlitz, A. (2008). "Innovation and Implementation in the Public Sector: An Examination of Public Entrepreneurship." Review of Policy and Research, Volume 25, Number 3, ss. 233-252.

Martinez, J.M. ve Richardson, W.D., (2008). Administrative Ethics in the Twentyfirst Century. New York: Peter Lang Publishing. 
Moon, M.J. (1999). “The Pursuit of Managerial Entrepreneurship: Does Organization Matter?" Public Administration Review, Vol. 59, No. 1, ss. 31-43.

(2000). “Organizational Committment Revisited in New Public Management: Motivation, Organizational Culture, Sector, and Managerial Level." Public Performance and Management Review, Vol. 24, No. 2, ss. 177-194.

Moon, M. J., \& deLeon, P. (2001). "Municipal reinvention: Managerial values and diffusion among municipalities." Journal of Public Administration Research and Theory, 11, 327-351.

Morris, M.H. ve Jones, F.F. (1999). "Entrepreneurship in Established Organizations: The Case of the Public Sector." Entrepreneurship Theory and Practice, Vol. 24, ss. 71-91.

Morris, M. H., \& Kuratko, D. F. (2002). Corporate entrepreneurship. Fort Worth, TX: Harcourt College.

Osborne, D. ve Gaebler, T. (1992). Reinventing Government: How the Entrepreneurial Spirit is Transforming the Public Sector. Addison-Wesley: Reading, Massachusetts.

Ott, J. S. ve Goodman, D. (1998). "Government Reform or Alternatives to Bureaucracy? Thickening, Tides, and the Future of Governing." Public Administration Review, Vol. 60, Issue: 6, s. 522545.

Pender, M. (2009). “The Meaning of Entrepreneurship: A Modular Concept." Journal of Industry, Competition and Trade, 9:77-99

Perry, J. L. ve Wise, L. R. (1990). "The Motivational Bases of Public Service." Public Administration Review, May/June. ss. 367-373.
Quince, T. ve Whittaker, H. (2003). “Entrepreneurial Orientation and Entrepreneurs' Intentions and Objectives." ESRC Centre for Business Research, University of Cambridge Working Paper No. 271. Nisan, 2011: http://www.cbr.cam.ac.uk/pdf/wp27 1.pdf

Ramamurti, R. (1986). "Public Entrepreneurs: Who They are and How They Operate." California Management Review, 28 , ss. $142-158$.

Romzek, B.S., (2000). "Dynamics of Public Sector Accountability in an Era of Reform." International Review of Administrative Sciences, 66 (1), ss. 21-44

Rutherford, M.W., Holt, D.T. ( 2007). “Corporate Entrepreneuship: An Emprical Look at the Innovatiness dimension and its antecedents." Journal of Organizational Change Management, Vol. 20, No. 3, ss. 429-446.

Schein, E., H. (2010). Organizational Culture and Leadership. San Francisco, CA: John Wiley \& Sons, Inc.

Skelcher, C. (2005). "Public-Private Partnerships and Hybridity" (ss.347-370) Ed. Ewan Ferlie, Laurence E. Lynn ve Christopher Politt. The Oxford Handbook of Public Management. Oxford University Press Inc. : New York.

Stevenson, H. H. ve Jarillo, C. J. (1990). “A Paradigm of Entrepreneurship: Entrepreneurial Management." Strategic Management Journal, Vol. 11, Special Issue: Corporate Entrepreneurship, 1727.

Tompkins, J. (2005). Organization Theory and Public Management. Boston, MA: Wodsworth Cengage Learning. 
Zampetakis, L.A., Moustakis, V.S. (2010). "An Expoloratory Research on the Factors Stimulating Corporate Enterpreneurship in the Greek Public Sector." International Journal of Manpower, Vol. 31, No. 8, ss.871-887. 
